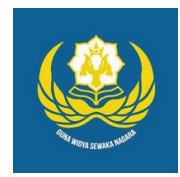

Jurnal Analogi Hukum

Journal Homepage: https://ejournal.warmadewa.ac.id/index.php/analogihukum

\title{
Hak Memelihara Anak setelah Putusnya Perkawinan karena Perceraian Menurut Hukum Adat Bali
}

\author{
I Wayan Ery Prayana Murtiawan*, I Nyoman Putu Budiartha dan Diah Gayatri Sudibya \\ Fakultas Hukum, Universitas Warmadewa, Denpasar, Bali-Indonesia \\ *ery.prayana@gmail.com
}

\begin{abstract}
How To Cite:
Murtiawan, I. W. E. P., Budiartha, I. N. P., \& Subidya, D. G. (2020). Hak Memelihara Anak setelah Putusnya Perkawinan karena Perceraian Menurut Hukum Adat Bali . Analogi Hukum. 2(1). 93-97. Doi: http://dx.doi.org/10.22225/.2.1.1630.93-97
\end{abstract}

\begin{abstract}
Behind the events of marriage and divorce, the existence of children is very important in the life of the Balinese people. Even many married couples are willing to divorce because it does not produce offspring or children in their marriages. The formulation of the problem in this study is: how is the right to care for children after the breakup of marriage due to divorce and how the position of the child according to Balinese customary law is after the termination of marriage due to divorce. The type of research used in the preparation of this proposal is normative legal research. The results of the discussion in this study are those who are obliged to care for children in divorce cases are the father of the child, because marriage according to Hindu law in Bali adheres to the Fatherhood system (Vederrechtelijk), so that the more privileged are purusa or male parties. About custody of children who are underage and breastfeeding usually the court gives custody of the child to the mother, this is due to humanitarian factors for the growth and development of the child. The position of the child after the breakup of marriage is that the child as heir and successor descendant is referred to as the term sentana the importance of the value of the child in accordance with the teachings of Hinduism that animates the lives of Balinese people.
\end{abstract}

Keywords: Children, Divorce and Balinese Customary Law

\begin{abstract}
Abstrak-Dibalik kejadian perkawinan dan perceraian, keberadaan anak sangat penting dalam kehidupan masyarakat Bali. Bahkan banyak pasangan suami istri rela cerai karena tidak membuahkan keturunan atau anak dalam perkawinannya. Rumusan masalah dalam penelitian ini yaitu: bagaimanakah hak memelihara anak setelah putusnya perkawinan karena perceraian dan bagaimanakah kedudukan anak menurut hukum adat Bali setelah putusnya perkawinan karena perceraian. Tipe penelitian yang dipergunakan dalam penyusunan proposal ini adalah penelitian hukum normatif. Hasil pembahasan dalam penelitian ini adalah yang berkewajiban memelihara anak dalam kasus perceraian adalah ayah dari anak tersebut, karena perkawinan menurut hukum Hindu di Bali menganut sistem Kebapaan (Vederrechtelijk), sehingga yang lebih berhak adalah pihak purusa atau pihak laki-laki. Tentang hak asuh anak yang masih dibawah umur dan sedang menyusui biasanya pengadilan memberikan hak asuh anak tersebut berada pada ibunya, hal tersebut disebabkan karena faktor kemanusiaan demi tumbuh kembang anak. Kedudukan anak setelah putusnya perkawinan adalah anak sebagai ahli waris dan penerus keturunan yang disebut sebagai istilah sentana pentingnya nilai anak tersebut sesuai dengan ajaran Agama Hindu yang menjiwai kehidupan masyarakat Bali.
\end{abstract}

Kata Kunci: Anak, Perceraian dan Hukum Adat Bali

\section{Pendahuluan}

Setiap orang yang akan memasuki fase berumah tangga pada umumnya mencitacitakan perkawinan yang kekal. Namun dalam proses perjalanan berumah tangga, tidak sedikit yang gagal untuk mewujudkannya. Peristiwa perceraian yang terjadi, baik di lingkungan terdekat maupun yang terjadi di tempat-tempat yang jauh, apalagi dengan adanya media televisi sudah merupakan fakta yang tak bisa dipungkiri. Seperti yang sering terjadi pada pasangan suami istri suatu studi kasus pada Pengadilan Negeri Gianyar.

Perceraian bukan hal yang tidak dibenarkan, baik menurut agama maupun menurut hukum. Dalam Peraturan Pemerintah Nomor 9 Tahun 1975 Pasal 19 menegaskan bahwa: 
Perceraian dapat terjadi karena alasanalasan sebagai berikut:

a. Salah satu pihak zina atau menjadi pemabuk, pemadat, penjudi, dan lain sebagainya yang sukar disembuhkan;

b. Salah satu pihak meninggalkan pihak lain selama 2 (dua) tahun berturut-turut tanpa izin pihak lain dan tanpa alasan yang sah atau karena hal lain di luar kemampuannya.

c. Salah satu pihak mendapat hukuman penjara 5 (lima) tahun atau hukuman yang lebih berat setelah perkawinan berlangsung;

d. Salah satu pihak melakukan kekejaman atau penganiayaan yang membahayakan pihak yang lain;

e. Salah satu pihak mendapat cacat badan atau penyakit dengan akibat tidak menjalankan kewajiban sebagai suami/ istri;

f. Antara suami dan istri terus-menerus terjadi perselisihan dan pertengkaran dan tidak ada harapan akan hidup rukun lagi dalam rumah tangga

Dari segi agama maupun hukum, perceraian itu dapat dilakukan, hanya saja harus ada alasan yang mendasar seperti suami atau istri berbuat zina, pemabuk, salah satu meninggalkan pasangan lebih dari 2 (dua) tahun berturut-turut dan alasan lain yang tidak bisa dimaafkan seperti istri tidak bisa melahirkan/ mempunyai anak sudah lebih dari 10 tahun.

Dalam pasal 80 dan 81 Nawano'dhayah Manawa Dharmasastra disebutkan bahwa Seorang suami dapat menceraikan istrinya apabila si istri peminum alkohol, bertabiat buruk, suka menentang baik kepada suami maupun kepada keluarga si suami, berpenyakit dan menyia-nyiakan tugas sebagai seorang istri setiap saat, tak berketurunan, semua anaknya meninggal dalam waktu sepuluh tahun, hanya mempunyai anak perempuan dalam waktu sebelas tahun, dan suka bertengkar (Pudja \& Sudharta, 2002).

Dibalik kejadian perkawinan dan perceraian tersebut diatas, keberadaan anak sangat penting dalam kehidupan masyarakat Bali. Hal tersebut sesuai dengan pendapat $P$. Windia sebagai berikut Banyak pasangan suami istri rela cerai karena tidak membuahkan keturunan atau anak dalam perkawinannya (Windia, 1989). Sehubungan dengan hal tersebut, bila terjadi perceraian bagaimana dengan status anak tersebut, siapa yang berhak memelihara menurut hukum Hindu.
Berdasarkan latar belakang tersebut diatas, maka permasalahan yang dianalisis dalam penelitian ini adalah hak memelihara anak setelah putusnya perkawinan karena perceraian dan kedudukan anak menurut hukum adat Bali setelah putusnya perkawinan karena perceraian.

\section{Metode}

Tipe penelitian yang dipergunakan dalam penyusunan jurnal ini adalah penelitian hukum normatif. Dalam penulisan ini terdapat bahanbahan hukum yang terdiri dari: (1) Bahan hukum primer yaitu bahan-bahan hukum yang mengikat, meliputi: Kitab Undang-Undang Hukum Perdata, Undang-Undang Republik Indonesia Nomor 1 Tahun 1974 tentang Perkawinan, Peraturan Pemerintah Nomor 9 Tahun 1975 tentang pelaksanaan UndangUndang Nomor 1 Tahun 1974 tentang Perkawinan dan Putusan Pengadilan Negeri Gianyar Nomor 114/Pdt/G/2011/Pn. Gir. Bahan hukum sekunder berupa semua publikasi tentang hukum yang bukan merupakan dokumen-dokumen resmi. Publikasi tentang hukum meliputi buku-buku teks, kamus-kamus hukum, jurnal-jurnal hukum, dan komentarkomentar atas putusan hukum (Marzuki, 2007).

Pengumpulan bahan hukum dilakukan dengan cara membaca, mempelajari, memahami, dan menganalisis buku atau literatur-literatur, ketentuan perundangundangan, makalah-makalah, majalah-majalah, ataupun informasi dalam bentuk lain seperti yang diperoleh dari internet, yang berhubungan erat dengan obyek kajian atau materi penelitian, kemudian dilakukan pencatatan dan pengutipan bagian-bagian yang penting.

\section{Hasil dan Pembahasan}

\section{Hak Memelihara Anak Setelah Putusnya Perkawinan Karena Perceraian}

Dalam undang-undang perlindungan anak, kedua orang tua memiliki hak yang setara dan sama untuk mengasuh memelihara, merawat serta melindungi hak-hak anak. Yang terpenting dalam hal ini adalah kemampuan orang tua untuk mengasuh dan memelihara anaknya. Akan tetapi majelis hakim dapat mencabut hak asuh anak, apabila salah seorang atau kedua orang tuanya ternyata berkelakuan buruk, dan melalaikan kewajiban terhadap anaknya. Hal ini sesuai dengan yang tercantum serta terdapat dalam Pasal 49 ayat (1) Undang-Undang Perkawinan yaitu yang menyebutkan :

Salah seorang atau kedua orang tua dapat dicabut kekuasaannya terhadap seorang anak 
atau lebih untuk waktu yang tertentu atas permintaan orang tua yang lain, keluarga anak dalam garis lurus keatas dan saudara kandung yang telah dewasa atau pejabat yang berwenang dengan keputusan pengadilan dalam hal-hal:

a. Ia sangat melalaikan kewajibannya terhadap anaknya;

b. Ia berkelakuan buruk sekali;

Secara umum dalam masyarakat Indonesia dikenal tiga macam sistem kekeluargaan. Sistem kekeluargaan tersebut adalah:

a. Sistem kekeluargaan patrilineal;

b. Sistem kekeluargaan matrilineal;

c. Sistem kekeluargaan parental (Soepomo, 1977).

Sistem kekeluargaan patrilineal misalnya dianut dalam masyarakat batak, Nias, Sumba, Bali dan lain-lain. Dalam sistem kekeluargaan, seorang istri dilepaskan dari hubungan hukum kekeluargaan dengan keluarga asalnya (orang tua kandung) selanjutnya masuk dalam lingkungan kekeluargaan suaminya. Anak-anak yang lahir dari perkawinan ini mendapatkan garis keturunan dari garis bapaknya, sementara dengan keluarga ibunya hanya mempunyai hubungan sosial dan moral saja, bukan hubungan hukum. Sistem kekeluargaan matrilineal dianut dalam masyarakat Minangkabau. Menurut sistem kekeluargaan ini, keturunan dilacak dari garis ibu sehingga anak yang lahir dari suatu perkawinan akan mendapatkan garis kekeluargaan dari gis ibunya (Koentjaraningrat, 1990). Berbeda dengan yang terjadi pada masyarakat patrilineal dan matrilineal yang menarik garis kekeluargaan secara unilateral (satu garis), dalam masyarakat yang menganut sisitem kekeluargaan parental, garis keturunan dilacak dari dua pihak (bilateral), yaitu baik dari garis bapak maupun ibu sehingga sistem kekeluargaan ini juga disebut sistem kekeluargaan keibu-bapaan. Sistem kekeluargaan ini dianut oleh masyarakat Jawa, Sunda, Aceh, Kalimantan, dan lain-lain.

Dalam hal ini seperti hak memelihara anak dan kedudukan anak menurut adat Bali setelah putusnya perkawinan karena perceraian, penulis kemukakan suatu contoh kasus perceraian sesuai Putusan PN Gianyar No: 114/ Pdt.G/2011/PN.Gir yang telah memutuskan antara lain bahwa: anak berada dibawah pengasuhan tergugat dengan memberikan hak kepada penggugat untuk setiap saat dapat mengunjungi anaknya sebagai wujud pencurahan rasa kasih sayang.
Kedudukan Anak Menurut Hukum Adat Bali Setelah Putusnya Perkawinan Karena Perceraian

Kedudukan anak menurut hukum adat Bali dimana penulis melihat dari kasus yang ada yaitu dapat dilihat dalam putusan Pengadilan Negeri Gianyar No: 114/Pdt.G/2011/ PN.Gir yang mengadili dan memeriksa perkara-perkara perceraian, pertimbangan-pertimbangan hakim dalam memutus perkara tersebut mengatakan:

Menimbang, bahwa apakah dalil atau alasan yang dikemukakan oleh Penggugat dalam surat gugatannya tersebut dapat dijadikan dasar/alasan untuk perceraian maka majelis akan mempertimbangkan sebagai berikut:

a. Bahwa berdasarkan keterangan saksi I Wayan Dana selaku Ayah kandung Penggugat yang menerangkan dipersidangan bahwa antara Penggugat dengan Tergugat sering terjadi pertengkaran dan setiap terjadi pertengkaran Penggugat pulang ke rumah orang tua untuk menghindari percekcokan didepan anak-anaknya.

b. Bahwa dulu tahun 2007 Penggugat sudah pernah menggugat cerai Tergugat, namun kemudian dicabut karena Tergugat membuat pernyataan akan mengubah sikap.

c. Bahwa saksi tahu Penggugat pulang ke rumah orang tuanya di mengwi kurang lebih 4 kali, karena cekcok dengan Tergugat.

d. Bahwa seorang Penggugat dengan Tergugat sudah tidak satu rumah lagi, Penggugat tinggal dirumah orang tuanya.

e. Menimbang, bahwa saksi I Ketut Ardana dipersidangan menerangkan bahwa saksi adalah Paman Penggugat, dimana saksi menerangkan bahwa Penggugat dan Tergugat sering cekcok, saksi mengetahuinya dari cerita Penggugat kepada saksi, dan setiap cekcok dengan Tergugat, Penggugat pulang ke rumah orang tua Penggugat.

f. Bahwa saat ini Penggugat dengan Tergugat sudah tidak lagi hidup serumah, dimana Penggugat tinggal bersama orang tuanya.

g. Menimbang, bahwa dengan adanya perselisihan dan pertengkaran antara Penggugat dengan Tergugat sebagaimana yang telah dipertimbangkan diatas, sampai gugatan ini diajukan ke Pengadilan Negeri Gianyar, Penggugat dengan Tergugat tidak pernah kembali berkumpul bersama dalam satu rumah lagi. 
h. Menimbang, bahwa mengenai keterangan 2 (dua) orang saksi yang diajukan Tergugat dipersidangan yaitu masing-masing saksi bernama I Wayan Dana dan I Ketut Ardana justru keterangan kedua orang saksi tersebut menerangkan bahwa antara Penggugat dengan Tergugat sudah 1 tahun tidak serumah lagi, dimana Penggugat tinggal bersama orang tuanya.

i. Menimbang, bahwa dari fakta dan kenyataan yang terungkap dipersidangan sebagaimana yang telah dipertimbangkan diatas, ternyata telah terjadi percekcokan dan pertengkaran dalam rumah tangga/perkawinan antara Penggugat dengan Tergugat yang tidak dapat didamaikan lagi dimana keduanya sudah tidak hidup rukun lagi dalam rumah tangga sebagaimana layaknya suami istri yang harmonis, karena keduanya sudah 1 (satu) tahun tidak serumah lagi, sehingga dengan demikian telah memenuhi alasan perceraian sebagaimana yang ditentukan dalam pasal 19 huruf F; Peraturan Pemerintah Nomor 9 Tahun 1975.

j. Menimbang, bahwa menurut UndangUndang Nomor 1 Tahun 1974 bahwa tujuan perkawinan adalah untuk membentuk kehidupan rumah tangga yang harmonis, sejahtera dan bahagia baik lahir maupun bathin, namun dalam perkawinan antara Penggugat dengan Tergugat tujuan yang demikian sudah tidak dapat tercapai akan tetapi malahan sebaliknya.

k. Menimbang, bahwa berdasarkan pertimbangan-pertimbangan tersebut diatas Majelis Hukum berpendapat bahwa antara Penggugat dengan Tergugat sudah tidak dapat diharapkan untuk hidup rukun kembali sebagaimana layaknya suami istri yang harmonis, dan apabila tetap dipaksakan dikhawatirkan akan berakibat buruk bagi kedua belah pihak.

1. Menimbang, bahwa dari uraian pertimbangan tersebut diatas, dan tanpa mengkaji lebih jauh penyebab timbulnya perpecahan dan percekcokan antara Penggugat dengan Tergugat yang tidak bisa diharapkan lagi akan hidup rukun dalam rumah tangga mereka, maka Majelis Hakim memandang patut dan bermanfaat bila perkawinan antara Penggugat dengan Tergugat dinyatakan putus karena perceraian.

m. Menimbang, bahwa dalam perkawinan antara Penggugat dengan Tergugat telah lahir 1 (satu) orang anak perempuan yang bernama Putu Ayu Diah Kencana Putri tersebut adalah hasil dari perkawinan antara Penggugat dengan Tergugat, maka sudah merupakan kewajiban bagi kedua belah pihak untuk memelihara, mendidik serta bertanggung jawab terhadap kelangsungan hidup dan masa depan anak-anak tersebut.

n. Menimbang, bahwa petitum gugatan Penggugat yang mohon agar Penggugat diberikan sebagai wali dari anak-anaknya.

o. Menimbang, bahwa terhadap petitum tersebut, Majelis Hakim berpendapat bahwa terhadap anak-anak yang lahir dari perkawinan Penggugat dan Tergugat ternyata masih di bawah umur dan memerlukan kasih sayang maka hak untuk mengasuh, mendidik dan memelihara anak tersebut.

p. Menimbang, bahwa sebagaimana diketahui perkawinan Penggugat dan Tergugat $(\mathrm{P}-1)$ dilakukan berdasarkan hukum adat Bali dimana Tergugat sebagai Purusa (status lakilaki). Dengan demikian anak-anak yang lahir dari perkawinan Penggugat dan Tergugat tersebut, akan masuk ke kekerabatan pada Tergugat sebagai Purusa. Dan oleh karena itu Majelis Hakim memandang cukup beralasan status anak Penggugat dengan Tergugat kekuasaannya ada pada Tergugat sebagai Purusa.

q. Menimbang, bahwa berdasarkan pertimbangan-pertimbangan tersebut diatas, Majelis Hakim berpendapat bahwa gugatan Penggugat dapat dikabulkan untuk sebagian.

Jadi berdasarkan putusan hakim tersebut diatas, penulis sependapat bahwa gugatan di kabulkan sebagian, dimana dalam putusan poin 12 bahwa kedudukan anak menurut hukum adat bali adalah mengikuti ayah/purusa sesuai dengan sistem kekeluargaan masyarakat adat Bali.

Berkaitan dengan hal tersebut, menurut hukum Hindu dan agama Hindu kedudukan anak setelah putusnya perkawinan karena perceraian menurut hukum adat Bali Bapak I Gede Masa, mengatakan:

Yang lebih berhak memelihara anak setelah putusnya perkawinan menurut hukum Hindu adalah suami dengan alasan bahwa masyarakat Bali menganut sistem kebapaan walau tidak boleh dilupakan ada pengecualian didesa tenganan pegringsingan masyarakat disana menunjukkan kecondongan kepada sistem kekeluargaan kebapak ibuan. Sistem kebapaan di Bali nyata nampak dimana istri 
memasuki keluarga suaminya. Demikian pula selanjutnya anak-anak akan terkait kepada keluarga ayah (suaminya) dan tidak ada hubungan lurus kepada keluarga ibunya. Kewajiban-kewajiban anak/cucu juga tertumpah kepada keluarga bapaknya serta hakhak dan kewajibannya (dari sana). Dengan keluarga ibunya hubungan demikian tidak dijumpai. Jika anak tersebut masih dibawah umur dan menyusui, maka yang berhak memelihara adalah ibunya dengan alasan sebagai berikut : bahwa secara psikologis, sejak bayi dilahirkan didunia dia mulai membentuk ikatan emosional dengan orang tuanya, terutama ibu ikatan ini bertambah kuat seiring dengan bertambah usianya. Pada masa-masa awal hidupnya, anak akan memiliki ikatan emosional paling erat dengan orang tua yang merawatnya/mengasuhnya dan memenuhi kebutuhan hidupnya sehari-hari baik itu kebutuhan fisik maupun psikis, ikatan emosional ini berkembang menjadi ikatan kasih sayang. Adanya ikatan kasih sayang ini merupakan hal yang penting dalam perkembangan anak karena merupakan dasar pembentukan pola hubungan dengan orang lain. Apabila ikatan kasih sayang anak dengan orang tuanya, terutama orang yang selalu merawat/ mengasuhnya dalam hal ini ibunya sangat penting dalam perkembangan kesehatan mental anak tersebut. Namun nanti setelah anak tersebut dewasa tanggug jawab atau yang bertanggung jawab adalah tetap ayahnya sesuai konsep agama Hindu adalah purusa atau kebapaan. (Wawancara dengan Bapak Masa I Gede, Advokat, pada tanggal 4 Januari 2019).

Apabila terjadi putus perkawinan baik karena kematian maupun karena perceraian, dalam masyarakat hukum asat Bali tentunya dilihat dari suami isteri dan keluarga bersangkutan, apakah mereka didalam ruang lingkup kemasyarakatan adat yang patrilineal, matrilineal atau parental. Karena di masyarakat bali menganut sistem kekerabatan patrilineal atau purusa, maka anak-anaknya masuk kedalam kerabat suami (keluarga ayah).

\section{Simpulan}

Berdasarkan uraian tersebut diatas dapatlah ditarik simpulan yang berkewajiban memelihara anak dalam kasus perceraian adalah ayah dari anak tersebut, karena perkawinan menurut hukum Hindu di Bali menganut sistem Ke-bapa -an (Vederrechtelijk), sehingga yang lebih berhak adalah pihak purusa atau pihak laki-laki. Tentang hak asuh anak yang masih dibawah umur dan sedang menyusui biasanya pengadilan memberikan hak asuh anak tersebut berada pada ibunya, hal tersebut disebabkan karena faktor kemanusiaan demi tumbuh kembang anak.

Kedudukan anak setelah putusnya perkawinan adalah anak sebagai ahli waris dan penerus keturunan yang disebut sebagai istilah sentana pentingnya nilai anak tersebut sesuai dengan ajaran Agama Hindu yang menjiwai kehidupan masyarakat Bali karena perkawinan yang dilaksanakan adalah secara adat Bali dan Agama Hindu yang menganut sistem kekeluargaan patrilinial. Hal inipun dilaksanakan di Banjar Tangkas Desa Kenderan Kecamatan Tegallalang Kabupaten Gianyar.

Bagi masyarakat khususnya pasangan suami istri didalam membina rumah tangga hendaknya tetap bisa saling menjaga keharmonisan, saling menghormati satu sama lain agar tercapai tujuan dari Undang-Undang Perkawinan Nomor 1 Tahun 1974 yaitu Perkawinan yang kekal berdasarkan Ketuhanan Yang Maha Esa. Sedangkan saran saya kepada orang tua yang sudah tidak bisa menyelamatkan perkawinannya memilih untuk mengakhirinya dengan perceraian tetap bisa bersama-sama baik ibu atau bapak tetap berkewajiban memelihara dan mendidik anak-anaknya untuk kepentingan anak itu sendiri.

Bagi orang tua dari pasangan suami istri hendaknya dapat meredakan/mendinginkan situasi anak-anaknya yang sedang menghadapi prahara rumah tangganya, sedapat mungkin mencegah terjadinya perceraian, demi cucu dan keutuhan rumah tangga mereka kembali.

\section{Daftar Pustaka}

Koentjaraningrat. (1990). Manusia dan Kebudayaan di Indonesia. Jakarta: Djambatan.

Marzuki, P. M. (2007). Penelitian Hukum. Jakarta: Kencana Prenada Media Grup.

Pudja, I. G., \& Sudharta, C. R. (2002). Manawa Dharma Sastra (Cetakan ke I). Jakarta: Pelita Nusantara Lestari.

Soepomo, R. (1977). Bab-Bab tentang Hukum Adat. Jakarta: Pradnya Paramita.

Windia, W. P. (1989). Danda Pacamil. Denpasar: Upada Sastra. 